\title{
POTENSI FISIK AIR TERJUN 12 TINGKAT DAN AIR TERJUN PANCURAN RAYO DI KABUPATEN KERINCI PROVINSI JAMBI
}

\author{
Leviana Winarti ${ }^{1}$, Fitriana Syahar, S.Si, M.Si ${ }^{2}$ \\ Program Studi Pendidikan Geografi, \\ Fakultas Ilmu Sosial, Universitas Negeri Padang \\ Email: levianawinarti@gmail.com
}

\begin{abstract}
ABSTRAK
Penelitian ini bertujuan untuk mendeskripsikan potensi fisik air terjun 12 tingkat dan air terjun pancuran rayo di Kabupaten Kerinci Provinsi Jambi. Jenis penelitian ini adalah deskriptif. Sampel yang ditarik secara Purposive Sampling. Data yang dikumpulkan melalui observasi, dokumentasi, teknik scoring dan analisis deskriptif. Penelitian ini menemukan (1) Ketinggian Air Terjun 12 Tingkat 15 meter dan Air Terjun Pancuran Rayo adalah 150 meter (2) Kemiringan Lereng Air Terjun 12 Tingkat 15-25 \% agak curam dan Air Terjun Pancuran Rayo adalah 15-25\% tergolong agak curam (3) Bentuk medan Air Terjun 12 Tingkat Bergunung dan Air Pancuran Rayo Bergelombang dan Perbukitan. (4) Jenis batuan Air terjun 12 Tingkat adalah Qvbk yaitu Batuan gunung api bungkuk sedangkan pada Air Terjun Pancuran Rayo Qvry yaitu Batuan Gunung Api Raya (5) Pola aliran sungai Air Terjun 12 Tingkat adalah dendritik dan Air Terjun Pancuran Rayo adalah Paralel.

Kata Kunci: Potensi Fisik, Air Terjun 12 Tingkat , Pancuran Rayo
\end{abstract}

\section{ABSTRACT}

This study aims to describe the physical potential of waterfall 12 tingkat and waterfall pancuran rayo in Kerinci district, Jambi Province. This type of research is descriptive. Samples were drawn by purposive sampling. Data gathered through observation, documentation, scoring techniques and descriptive analysis. This study found (1) Waterfall 12 Tingkat was 15 meters tall and Waterfall Pancuaran Rayo was 150 meters tall, (2) both waterfalls' slopes were 15-25\% slightly steep, (3) the land shape of both locations was formed by corrugated plains and hills, (4) Rock type in the former area was mostly identified as Qvbk which was the rocks from Bungkuk Volcano while in the latter area it was Qvry, the rocks from Raya Volcano, (5) the stream patterns were Dendritic (Waterfall 12 Tingkat) and Paralel (Waterfall Pancuran Rayo)

Keywords: Physical Potensials, Waterfall 12 Tingkat, Waterfall Pancuran Rayo

\footnotetext{
${ }^{1}$ Mahasiswa Program Studi Pendidikan Geografi untuk wisuda September 2018

${ }^{2}$ Dosen Jurusan Geografi Fakultas Ilmu Sosial Universitas Negeri Padang
} 


\section{PENDAHULUAN}

Secara umum wilayah Kabupaten Kerinci dapat dikelompokkan dalam beberapa satuan morfologi yaitu dataran, perbukitan yang begelombang sampai perbukitan sedang dan pergunungan. Kondisi ini menjadi modal besar bagi Kabupaten Kerinci. Dari pemaparan diatas bahwa Kabupaten Kerinci memiliki banyak Air terjun, di dalam RENSTRA (Rancangan Strategis)Kabupaten Kerinci dikenal sebagai Kabupaten yang memiliki panaroma alam terindah di Propinsi Jambi. Keelokannya menjadi terkenal dengan keberadaan gunung Kerinci yang merupakan gunung tertinggi di Sumatera.

Air terjun merupakan salah satu dari bentang alam yang menarik.Salain sebagai wisata, air terjun juga dapat dimanfaatkan sebagai sumber mata air bagi penduduk sekitar.Air terjun terdiri atas berbagai bentuk dan ukuran.Meskipun demikain air terjun memiliki standarisasi tersendiri dalam pendeskripsiannya. Menurut Terdapat tujuh kelompok penggolongan air terjun berdasarkan kenampakannya secara fisik. (Glaubitz 2001) menyatakan bahwa, "(a) Cascade, merupakan air terjun dengan skala kecil yang umum digunakan untuk menjelaskan bagian dari air terjun. (b) Cataract, merupakan air terjun yang mempunyai ketinggian lebih dari 30 meter dan mempunyai kekuatan air yang besar. (c) Chute, merupakan air terjun yang berbentuk sempit dan mempunyai kekuatan besar umumnya berada di antara dua buah batuan besar atau pada dinding jurang dan lebar dinding air terjun yang sempit yaitu kurang dari dua meter. (d) Slide (luncur) merupakan tipe air terjun yang terbentuk kerena aliran sungai yang mengalir mengikuti kemiringan permukaan dinding tebing, dengan kemiringan tebing kurang dari $70^{\circ}$. (e) Over hanging ledge falls (birai yang menggantung), tipe air terjun yang pancuran airnya menonjol keluar dari air terjun atau air tidak menyentuh dinding air terjun. (f) Parallel, tipe ini terbentuk dari dua buah air terjun yang letaknya berdampingan satu sama lainnya. (g) Waterfall, yaitu bagian dari sungai yang jatuh secara vertical ke suatu tempat dan umumnya lebarnya lebih dari dua meter.

Air terjun adalah air yang keberadaannya vertical pada jatuhan di profil kemiringan sungai (Leet \& Judson, 1965), yang tingginya $>5$ meter dengan kemiringan tebing >250.Morfometri air terjun yang dimaksud adalah tinggi air terjun, kemiringan tebing air terjun, lebar air terjun dan bentuk air terjun. Adapun klasifikasi atau potensi fisik air terjun dilihat dari aspek geomorfologi. Menurut (Leet \& Judson, 1965) menyatakan bahwa, "Aspek Morfologi, Wilayah ketinggian, Wilayah Lereng, Wilayah Bentuk Medan, Pola Aliran Sungai, Jenis Batuan".

Menurut koesoemadinata (1980),

secara umum klasifikasi acuan menyangkut genesa pmbentukannya dapat dibagi menjadi tiga kelas yaitu: batuan beku (igneous rocks), batuan malihan atau batuan metamorf (metamorphic rocks), dan batuan sedimen (sedimentary rocks).

Air terjun 12 tingkat dan air terjun Pancuran Rayo memiliki karakteristik fisik yang berbeda dan keunikan sumber daya alam yang berbeda juga. Berdasarkan hal tersebut kegiatan wisata untuk masingmasing Air terjun nantinya akan berbeda pula menurut (Mhd.Rizky dalam jurnal nya Analisis Potensi dan Strategi Pengembangan Wisata Alam Air Terjun Silimalima di Kabupaten Tapanuli Selatan) mengatakan air terjun dengan keadaan tebing curam dengan bantuan besar di sekelilingnya bisa di manfaatkan untuk acara lomba lintas alam karena memiliki jalur-jalur tracking yang cukup menantang namun tidak begitu ekstrim selain itu juga bisa untuk event-event olah raga outdoor. Selain itu apabila ketinggian air terjun kurang dari 5 meter aliran sungai yang terbentuk dari jatuhan lebih kecil ini memiliki arus air yang tenang bisa digunakan untuk mandi. 
Berdasarkan uraian di atas maka penulis tertarik untuk meneliti tentang Air terjun di Kabupaten Kerinci dan potensipotensi yang ada dengan mengambil judul "Potensi Fisik Air Terjun 12 Tingkat Dan Air Terjun Pancuran Rayo Di Kabupaten Kerinci Provinsi Jambi

\section{METODE PENELITIAN}

Jenis penelitian ini adalah deskriptif, yaitu berusaha mengungkapkan tentang analisis geografis terhadap potensi fisik Air terjun di Kabupaten Kerinci secara apa adanya sesuai dengan kenyataan yang ditemukan di lapangan. Deskriptif adalah pengolahan data dengan melakukan proses mengatur, mengurutkan data yang terkumpul yang terdiri dari catatan-catatan lapangan, baik melalui wawancara, observasi, dokumentasi. Sampel dalam penelitian ini adalah Air terjun 12 Tingkat dan Air Terjun Pancuran Rayo. Pengambilan lokasi penelitian ini dilakukan dengan purposive sampling. Data tersebut diatur dan diurutkan sesuai kebutuhan peneliti, sehingga informasi kualitatif tersebut disusun atas pikiran, intuisi, pendapat dan kriteria tertentu (Moh. Nazir :1998).

Lokasi penelitian ini adalah Air Terjun 12 Tingkat terletak di desa Talang Kemulun Kecamatan Danau Kerinci dan Air Terjun Pancuran Rayo terletak di Desa Dusun Baru Pulau Tengah Kecamatan Keliling Danau Kabupaten Kerinci. Seperti yang terlihat pada gambar 1 :

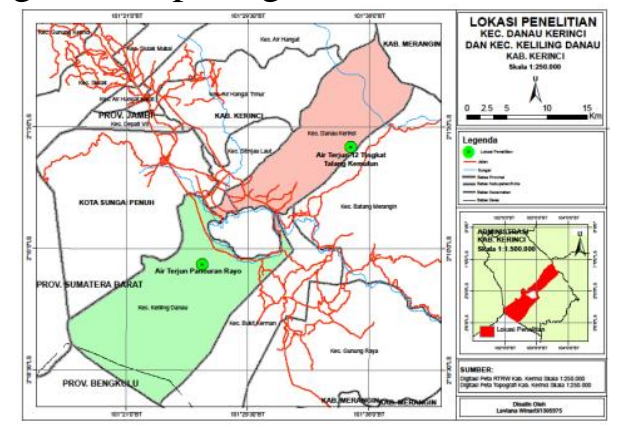

Gambar 1: Peta Lokasi Penelitian
Potensi Fisik, Ketinggian, Lereng, Bentuk Medan, Jenis Batuan, Pola Aliran Sungai

Seluruh data yang berbasis spasial seperti faktor fisik daerah penelitian disusun melalui system GIS dengan menggunakan Software Arc Gis 10.1 Untuk Melihat Fisik, bentuk medan, jenis batuan, pola aliran sungai, kerapatan sungai di wisata alam air terjun $d$ Kabuaten kerinci. Membuat peta bentuk medan yang diolah peta Rupa Bumi dengan cara overlay peta ketinggian dengan peta lereng. Membuat peta jenis batuan, yang diperoleh dari peta geologi.

Membuat peta pola aliran sungai dengan cara digitasi aliran sungai yang ada. Pembangian pola mengacu kepada pola aliran menurut Lobeck (1939) yaitu dendritik, trellis, rectangular dan radial. Sedangkan untuk melihat potensi fisik air terjun dan pemanfaatannya air terjun dengan keadaan tebing curam dengan bantuan besar di sekelilingnya bisa di manfaatkan untuk acara lomba lintas alam karena memiliki jalur-jalur tracking yang cukup menantang namun tidak begitu ekstrim selain itu juga bisa untuk eventevent olahraga outdoor. Selain itu apabila ketinggian air terjun kurang dari 5 meter aliran sungai yang terbentuk dari jatuhan lebih kecil ini memiliki arus air yang tenang bisa digunakan untuk mandi.

Setelah itu untuk melihat potensi fisik untuk dikembangkan air terjun Pancuran Rayo dan Air Terjun 12 Tingkat dilakukan teknik penskoran yang dianalisis menggunakan rumus kelas interval:

$$
\begin{aligned}
& \text { Kelas interval } \\
& \mathrm{K}=1+3.3 \log (\mathrm{n}) \\
& \mathrm{R}=\text { data tertinggi }- \text { data terendah } \\
& \mathrm{P}=
\end{aligned}
$$

Keterangan:

$\mathrm{K}=$ Kelas interval

$\mathrm{R}=$ Rentan data $\mathrm{R}$

$\mathrm{P}=$ Panjang interval 


\section{HASIL DAN PEMBAHASAN}

\section{Ketinggian Air Terjun 12 Tingkat dan Air Terjun Pancuran Rayo}

Secara geografis, Air Terjun Pancuran Rayo terletak pada Dusun Baru Pulau Tengah, Kecamatan Danau Keliling, sedangkan Air Terjun 12 Tingkat terletak pada Dusun Baru Pulau Tengah, Kecamatan Danau Kerinci, Kabupaten Kerinci, Provinsi Jambi.Untuk menikmati keindahan air terjun 12 Tingkat dan Pancuran Rayo, pengunjung setidaknya harus menempuh jarak 23 kilometer dari Kota Sungai Penuh. Ketinggian air terjun merupakan pemandangan yang mengagumkan adapun ketinggian Air Terjun Pancuran Rayo dan Air Terjun 12 Tingkat dapat dilihat pada tabel 1:

Tabel 1. Ketinggian Air Terjun Pancuran Rayo dan 12 Tingkat

\begin{tabular}{|c|c|c|c|c|}
\hline No & Nama Air Terjun & Keterangan & $\begin{array}{l}\text { Tinggi } \\
\text { (m) }\end{array}$ & Kategori \\
\hline 1 & $\begin{array}{c}\text { Air Terjun } \\
\text { Pancuran Rayo }\end{array}$ & & 150 & Tinggi \\
\hline 2 & $\begin{array}{c}\text { Air Terjun } 12 \\
\text { Tingkat }\end{array}$ & $\begin{array}{c}\text { Tingkat } 1 \\
\text { Tingkat } 2 \\
\text { Tingkat } 3 \\
\text { Tingkat } 4 \\
\text { Tingkat } 5 \\
\text { Tingkat } 6 \\
\text { Tingkat } 7 \\
\text { Tingkat } 8 \\
\text { Tingkat } 9 \\
\text { Tingkat } 10 \\
\text { Tingkat } 11 \\
\text { Tingkat } 12 \\
\end{array}$ & $\begin{array}{l}16 \\
14 \\
2 \\
3 \\
1 \\
3 \\
5 \\
6 \\
1 \\
2 \\
2 \\
3 \\
\end{array}$ & $\begin{array}{l}\text { Sedang } \\
\text { Sedang } \\
\text { Rendah } \\
\text { Rendah } \\
\text { Rendah } \\
\text { Rendah } \\
\text { Rendah } \\
\text { Rendah } \\
\text { Rendah } \\
\text { Rendah } \\
\text { Rendah } \\
\text { Rendah } \\
\end{array}$ \\
\hline
\end{tabular}

2. Lereng Air Terjun 12 Tingkat dan Air Terjun Pancuran Rayo

Lereng adalah kenampakan permukan alam disebabkan adanya beda tinggi apabila beda tinggi dua tempat tesebut di bandingkan dengan jarak lurus mendatar sehingga akan diperoleh besarnya kelerengan. Dari klasifikasi kelas lereng pada Air Terjun Pancuran Rayo adalah 15-25\% dengan wilayah lereng agak curam dan Air Terjun 12 Tingkat 25-40\% dengan wilayah lereng curam. Seperti yang terlihat pada gambar 2:

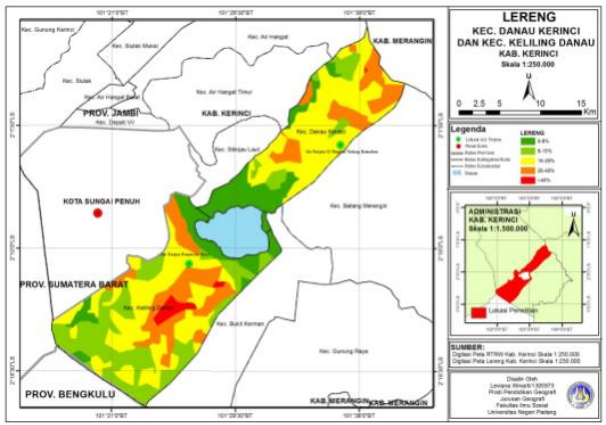

Gambar 2: Peta Lereng

3. Bentuk Medan Air Terjun 12 Tingkat dan Air Terjun Pancuran Rayo

Dari kalasifikasi wilayah Bentuk Medan hasil overlay peta topografi dan peta lereng Air Terjun Pancuran Rayo adalah bergelombang, perbukitan dengan kelas lereng 15$25 \%$ dan perbedaan tinggi $50-300 \mathrm{~m}$ dan Air Terjun 12 Tingkat Pengunungan dengan kelas lerang 25$40 \%$ dan perbedaan tinggi $>300 \mathrm{~m}$. Dapat di lihat pada gambar 3:

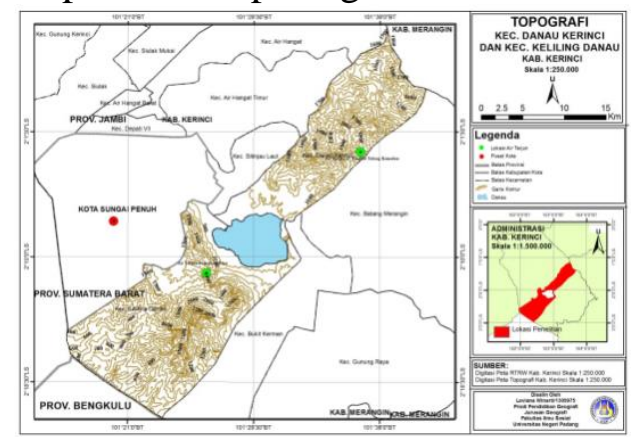

Gambar 3: Peta Topografi

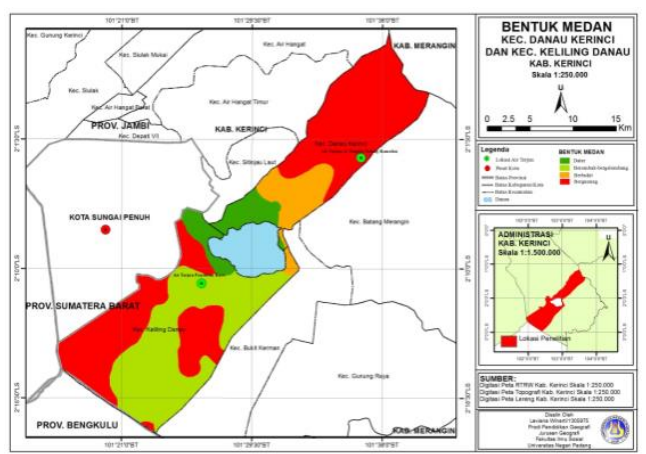

Gambar 4: Peta Bentuk Medan

4. Jenis Batuan Air Terjun 12 Tingkat dan Air Terjun Pancuran Rayo 
Berdasarkan jenis batuan pada Air Terjun Pancuran Rayo dan Air Terjun 12 Tingkat adalah Qvry adalah batuan gunungapi raya dan Qvbk batuan gunung api bungkuk. Dapat dilihat pada gambar 5:

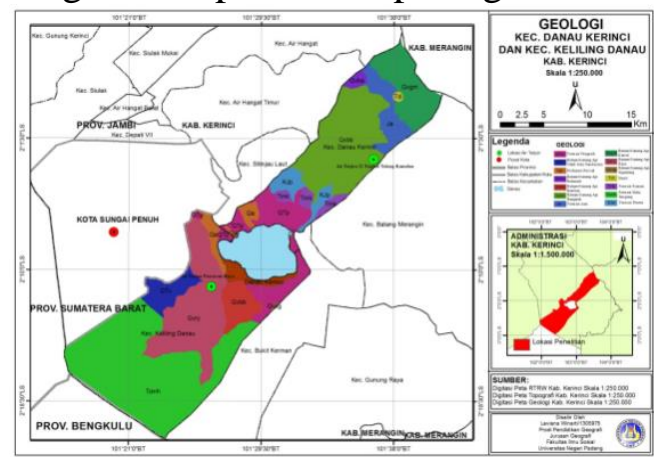

Gambar 5: Peta Geologi

\section{Pola Aliran Sungai Air Terjun 12 Tingkat Air Terjun Pancuran Rayo}

Pola aliran sungai Pada Air Terjun Pancuran Rayo adalah paralel dan Air Terjun 12 Tingkat adalah dendritik. Dapat dilihat pada gambar 6:

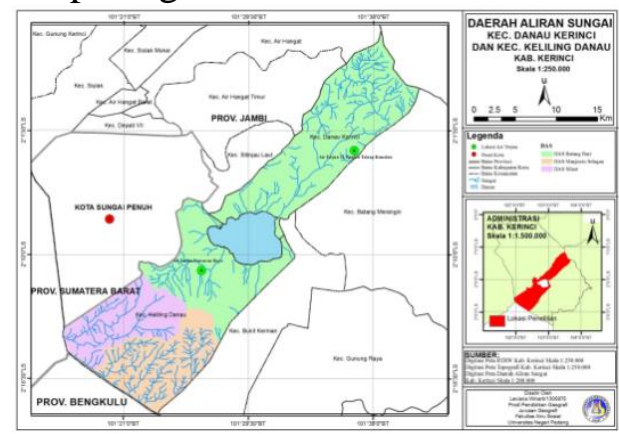

Gambar 6: Peta Aliran Sungai

\section{Potensi Fisik Air Terjun Air Terjun 12 Tingkat dan Pancuran Rayo}

\section{a. Air Terjun 12 Tingkat}

Berdasarkan potensi fisik Terjun 12 Tingkat termasuk pada tipe Cascade dengan tinggi air terjun 15 $\mathrm{m}$, wilayah bentuk medan Bergunung dengan pola aliran sungai dendritik, lereng 25-40 \%, jenis batuan Qvbk dengan wilayah ketinggian $1620 \mathrm{mdpl}$ termasuk pada kategori Wilayah Pegunungan Tinggi.

Pengolahan data dengan memberikan skor pada setiap karakteristik air terjun diolah dengan kelas interval didapatkan hasil bahwa
Air Terjun 12 Tingkat termasuk dalam kategori rendah dimana dilihat dari bentuk medan yang sulit, wilayah pegunungan yang tinggi dan akses menuju ke Air terjun tersebut sulit.

\section{b. Air Terjun Pancuran Rayo}

Berdasarkan potensi fisik Air Terjun Pancuran Rayo termasuk pada tipe Cataract,dengan tinggi air terjun $150 \mathrm{~m}$, wilayah bentuk medan bergelombang dan perbukitan dengan pola aliran sungai dendritik lereng 15$25 \%$, jenis batuan Qvry dengan wilayah ketinggian 1620 mdpl termasuk pada kategori Wilayah Pegunungan Tinggi. Sehubungan dengan hal tersebut maka potensi untuk Air terjun Pancuran Rayo berpotensi sebagai Lintas alam, mandi dan aur jeram, untuk lintas alam. Berdasarkan hasil analisis data dengan melakukan scoring terhadap karakteristik fisik air terjun dan dianalisis menggunkan kelas interval.

Berdasarkan potensi fisik untuk Air Terjun Pancuran Rayo adalah dengan kategori rendah dilihat dari bentuk medan, wilayah pegunungan yang tinggi, serta akses untuk menuju Air Terjun sangat sulit apabila tetap ingin pergi sebaiknya memperhatikan cuaca apabila dalam potensi hujan sebaiknya tidak melakukan nya karena air terjun lebih besar dari biasanya.

\section{PENUTUP}

Dari hasil penelitian potensi fisik air terjun 12 tingkat dan pancuran rayo dapat di ambil kesimpulan sebagai berikut:

1. Ketinggian Air Terjun 12 Tingkat 15 meter dan Air Terjun Pacuran Rayo adalah 150 meter

2. Kemiringan Lereng Air Terjun 12 Tingkat 15-25\% agak curam dan Air Terjun Pancuran Rayo adalah 15-25 \% tergolong agak curam. 
3. Bentuk medan Air Terjun 12 Tingkat Bergunung dan Air terjun Pancuran Rayo Bergelombang dan Perbukitan.

4. Jenis batuan Air Terjun 12 Tingkat adalah Qvbk yaitu Batuan gunung api bungkuk sedangkan pada Air Terjun Pancuran Rayo Qvry yaitu batuan Batuan Gunung Api Raya.

5. Pola aliran sungai Air Terjun 12 Tingkat adalah dendritik dan Air Terjun Pancuran Rayo Paralel.

\section{SARAN}

Berdasarkan hasil penelitian dan pembahasan maka dapat disarankan perlu kerjasama antara pemerintah bersama masyarakat dan elemen terkait seperti Dinas Pariwisata untuk mempromosikan Air terjun 12 Tingkat dan Pancuran Rayo. Selain itu pemerintah harus segera memperhatikan keadaan air terjun yang ada, agar keselamatan pengunjung bisa terjaga.

\section{DAFTAR PUSTAKA}

Glaubitz, 2001. Genetic impacts of different silviculturalpractices in native eucalypt forests. In: Matyas, Cs (Ed) Forest Genetics and Sustainability. Journal. Kluwer Academic Publishers, Dordrecht, the Netherlands, pp 183-195.

Koesoemadinata, 1980. Geologi Minyak dan Gasbumi. Edisi kedua, Jilid 2.Penerbit ITB.

Lett, Judson $1965 . \quad$ Pariwisata. Jakarta:Penerbit Erlangga.

Lobeck.1939.Geomorphology, An Introduction to The Study of Land scape, Mc Graw-Hill Book Co., Inc., New York \& London.

Mhd. Rizky dkk, Analisis Potensi dan Strategi Pengembangan Wisata Alam Air Terjun Silimalima di Kabupaten Tapanuli Selatan.
Program Studi Kehutanan,

Fakultas Kehutanan, Universitas Sumatera Utara, Jl. Tri Dharma Ujung No.1 Kampus USU Medan. Nazir, Moh. 1998. Metode Penelitian . Jakarta. Ghalia Indonesia.

Sandy. 1985. Geografi Regional Indonesia.Puri Margasari. Jakarta. 